\title{
When Perception Becomes Reality: The Creation and Reproduction of Images of Traditional Taonga Whakairo (Māori Carvings): An Introduction
}

\section{Introduction}

This paper explores ways of seeing as they relate specifically to traditional taonga whakairo (Māori carvings). The focus here is not on the carvings themselves, but on the effects on the perception of these objects caused by reproducing images of taonga whakairo in books and in electronic form. Among the themes considered are the absence of neutrality in photographs, the reduction of traditional taonga whakairo to the status of art or antiquities, and the re-mystification of a selection of these items through the same medium, using the case of the Te Mãori exhibition as an example. The conclusion reached is that in all instances, photographs tend to subvert the objects that they portray in some way.

\section{Carved Images}

The Biblical injunction that carved images should not be worshipped (Exodus 20:4) testifies to the power of carvings of deities on the orientation of people's devotion. In traditional Māori society, carvings of ancestors and deities were considered tapu - so much so that those who made them, the places where they were produced, and even the off-cuts of the wood used were also regarded as highly sacred. (Earle, 1832; 
Wakefield, 1845; Angas, 1866; Ryan \& Crotts, 1998; Skinner, 2008).

From the early nineteenth century, though, as the forces of European colonisation began to bear down on traditional Māori society, carvings were condemned by some Europeans as demonic (Wade, 1842; Angas, 1847; Brown, 1851), and the relics of an earlier, supposedly 'uncivilised' era (Craik, 1830; Swainson, 1859; Carleton, 1884). Gradually, although never completely, the potency that these carvings traditionally possessed was weakened as the circumference of British values expanded in the colony (Martin, 1845; Busby, 1866; Williams, 1867), and hand-in-hand with their diminished status was often a physical demise. An unknown number of traditional taonga whakairo destroyed at the behest of missionaries, others eventually crumbled after being abandoned to long exposure to the elements, while the traditions and methods associated with producing these carvings became an endangered practice (Mead, 1986).

Ironically though, at the same time as the physical examples of traditional taonga whakairo became scarcer, images of them - predominately in the form of photographs (but also initially engravings) reproduced in books proliferated (Earle, 1832; Polack, 1838; Burton, c. 1885; Best, 1927). This transition to mass-produced images of traditional taonga whakairo enabled many thousands of viewers to look at these objects (albeit in two-dimensional form) when they otherwise would not have had the opportunity. However, there are several implications of seeing these carvings in this form, including the absence of neutrality in photographs, the reduction of traditional taonga whakairo to the status of art or antiquities, and the re-mystification of a selection of these items through the same medium, of which images from the Te Māori exhibition were an example. 
Given the constraints of space, there is no intent here to present a comprehensive survey of the thematic issues supplemented with substantial supporting examples. Instead, a few salient aspects of the implications of traditional taonga whakairo being represented in photographs are examined, with an adjoining example or two where necessary to illustrate the point.

\section{Neutrality}

No photographic image is neutral. The photographer selects the subject, and then dictates the angle, composition of elements, lighting, and often the accompanying label. In addition, it must be presumed that there is a motive behind almost every photograph. Just as important, though, it is what is not contained in the photograph can affect the viewer's perception of the subject (Berger, 1972). Photographs exclude, or at the very least, distort the cultural context and history of the subject, creating a contextual vacuum into which the viewer's presumptions are deposited. And in some instances, viewers' presumptions have been guided both by the images and their accompanying text.

In the case of Elsdon Best's exhaustive writings on aspects of traditional Māori society, illustrations of traditional taonga whakairo were typically included in his text almost as twodimensional museum exhibits of the sort common at the time. As an example, a photograph (fig. 1) of a waka kererū in Best's 1941 publication The Maori (Best, 1941) takes up the entirety of the space in the frame. The background is an amorphous colour, positioned to deny the image even its own shadow. The significance of the carvings on the object is reduced to mere embellishment by the absence of any attendant text explaining their purpose and what they represent. 


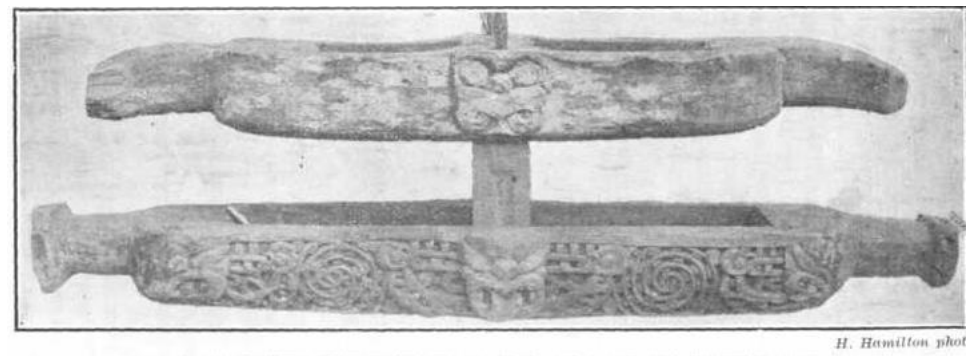

Two waka kerery-troushs fllted with water and set with snares for taking wood pigeons.

Fig. 1, Photograph of two waka kereru, in Elsdon Best's The Maori, 1941.

In this example, as in numerous others, it is implied that either the function of the object or its decoration ought to be the primary concern of the viewer (Taylor, 1855; Hiroa, 1949; Best, 1934). Moreover, the absence of any visual context is strongly suggestive that this is more of a relic than any object belonging to a current culture. In this way, the material aspects of Maori culture, including the carvings, are relegated to the status of museum exhibits belonging to a culture that no longer exists. Thus, the image becomes a device which confirms the culture is at once archaic and if not extinct, then very close to it. Ironically, the very features of these sorts of images that outwardly suggest neutrality - the lack of any other elements in the picture - are the very traits that load the image with presumptions about the status of the culture that produced the objects.

However, even when visual context was included in photographs of taonga whakairo, the result could be just as culturally debilitating. James Cowan - another prolific writer on aspects of Māori culture - included in a 1930 publication a photograph (fig. 2) of the interior of a wharenui in Rotorua (Cowan, 1930). Here the carvings are in situ rather than having been extracted and mounted as exhibits in a museum (Hiroa, 1949). 


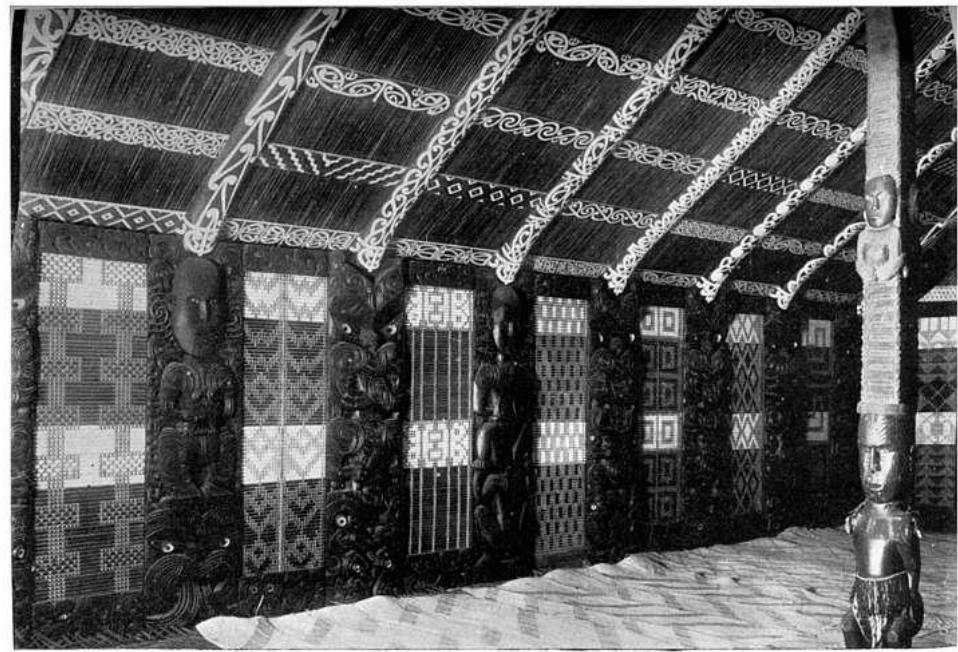

Fig. 2, Photograph of wharenui in Rotorua, in James Cowan's The Maori: Yesterday and To-Day, 1930.

However, this apparent concession to a more authentic context is ambiguous. For a start, there are no people in the wharenui (which makes it harder for the viewer to develop a sense of scale of the building), and because only the interior is revealed in the photograph, there is nothing to indicate in the image that this wharenui is not itself sited in a museum (as was the case with some wharenui by this period in New Zealand). Furthermore, an artificial light source has evidently been used to enhance the detail of the interior. The angle of the light, coupled with its intensity, illuminates this wharenui to an extent that would not have normally been familiar to those who used it.

And even when there seems to be a more indigenous context in which taonga whakairo feature, some of the compositional elements conspire against this authenticity. This can be seen in an image of the Takitimu Marae in Wairoa 
(fig. 3), published in 1944 (Mitira, 1944). Firstly, the setting is carefully cropped, with a small strip of lawn in the foreground, and a background of just sky, which gives no clue as to its broader location.

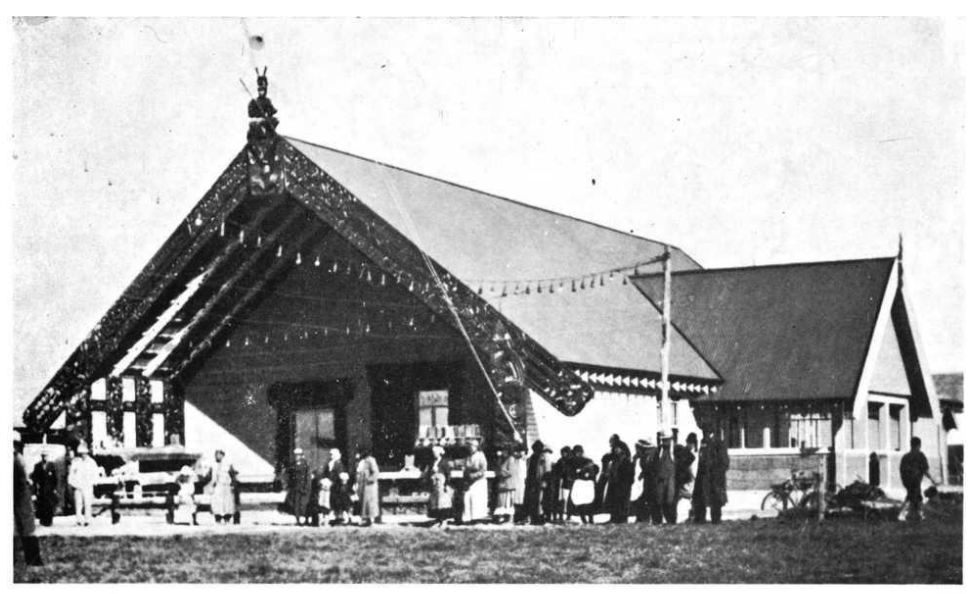

TAKITIMU House, WAI-ROA, H.B.

Fig. 3, Photograph of Takitimu Marae, in Tiaki Mitira's Takitimu, 1944.

Then there is the row of people lined up outside, posed for the photograph. For the viewer, this gives no indication of the cultural attachment of the people to the building, and the significance to them of the taonga whakairo under which they are standing. All that the viewer can conclude is that carvings are little more than decorations - a more ornate version of the bargeboards and gables at the side of the building.

In all these re-contextualisations of traditional taonga whakairo, what are missing are: any indications of the history of the taonga whakairo; the cultural intersection between these carvings and the communities from where they emerged; the significance of the wider location to the specific settings of the taonga whakairo; and any notion that they retained a 
metaphysical dimension for Māori at the time the photographs were taken.

\section{Taonga Whakairo as Art}

As a corollary to the cultural neutering of traditional taonga whakairo through the medium of photography, there was a compensating tendency to evaluate carvings based on their aesthetic values as seen from a distinctly European perspective. The following extract, from a popular interwar publication, typifies this approach:

One of the most striking characteristics of the Maori is his carvings - handsome and intricate in design. Handsome is used advisedly, yet it may be that that description is only understood after some careful and sympathetic study of carving technique. The so-called decorative woodwork on many of our pakeha dwellings is far less interesting, and lacks those evidences of art which are found in Maori carvings. (Godber, 1934, p. 39).

In the New Zealand Centennial Exhibition in Wellington in 1940, the notion of taonga whakairo fulfilling merely decorative functions was reinforced in the Exhibition's official guide:

Stalls are provided adjacent to the meeting house where Maori people representing various tribes display and sell Maori works of art and where the public have an opportunity of viewing and purchasing exhibits of carving and weaving (Centennial Branch, 1940, p. 33). 
This was taking the aesthetic value of taonga whakairo to its ultimate conclusion by commodifying carvings (Willis \& Fry, 1988), and making them tradable, with values based solely on their decorative traits according to the tastes of primarily European purchasers. One of the consequences of this was that the original meanings and purposes of the designs of taonga whakairo were altered (Jackson, 1999). To some extent, the perception of taonga whakairo as commodities, with values established on the culturally-based and subjective measure of design 'merit', increased in proportion with the decline in interpreting these carvings in the context of their traditional symbolism, spiritual significance, and historical resonance.

\section{Taonga Whakairo as Antiquities}

On the surface, it might appear that photographing traditional taonga whakairo was a culturally 'safe' way of disseminating these deigns without making the objects themselves tradable commodities. In addition, it was also a way of preserving details of these objects long after they actual items had suffered from the subsequent effects of exposure to the elements. However, the counterpoint to this aspect of photographing carvings is that they were repositioned in the popular imagination as relics of a Māori antiquity.

Even in the late nineteenth century, this representation of traditional taonga whakairo as antiquities - remote in time and relevance from the present age - was already underway (Rusden, 1883). By the twentieth century, the portrayal of traditional Māori carvings as antiquities was almost the norm in photographs of these objects. In Best's 1941 book The Maori, a photograph of a carved pātaka (storehouse) (fig. 4) showed this heavily-carved building in a bush setting (Best, 1941). This has a semblance of authenticity about it - even if 
only because it is sited in its original location as opposed to being in a museum.

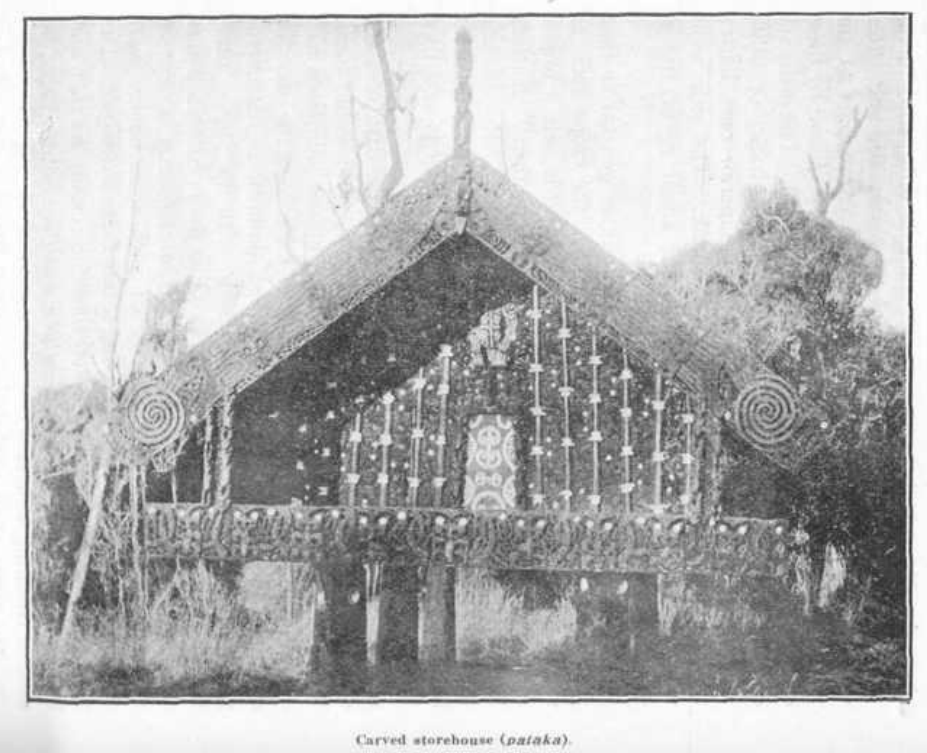

Fig. 4, Photograph of carved pātaka, in Elsdon Best's The Maori, 1941.

However, there is no sign of any people having been in the vicinity, and the composition of the photograph, particularly the inclusion of lifeless tree branches in the background, evoked notions of the Picturesque - which for European artists had involved the glorification of ancient ruins in landscapes that echoed with the sense of long-since fallen civilisations (Gilpin, 1768). Motifs of the Picturesque abounded in photographs of traditional taonga whakairo, particularly in the first half of the twentieth century, emphasising a supposed dichotomy between the traditional cultural values these carvings embodied and reflected, and present-day Māori 
society. In such a subtle way, Māori in the first half of the twentieth century were implicitly denied their cultural and spiritual history by the suggestive nature of images such as this, which created a separation between the era of taonga whakairo and the modern age.

In a similar vein, Robley's (1896) juxtaposition of a Māori with a moko (a symbol of 'bygone' era in the culture) with the carved prow of a waka (fig. 5), had the similar effect of driving a wedge between the epoch when carving predominated and the more 'advanced' period that coincided with the establishment of European culture in New Zealand.

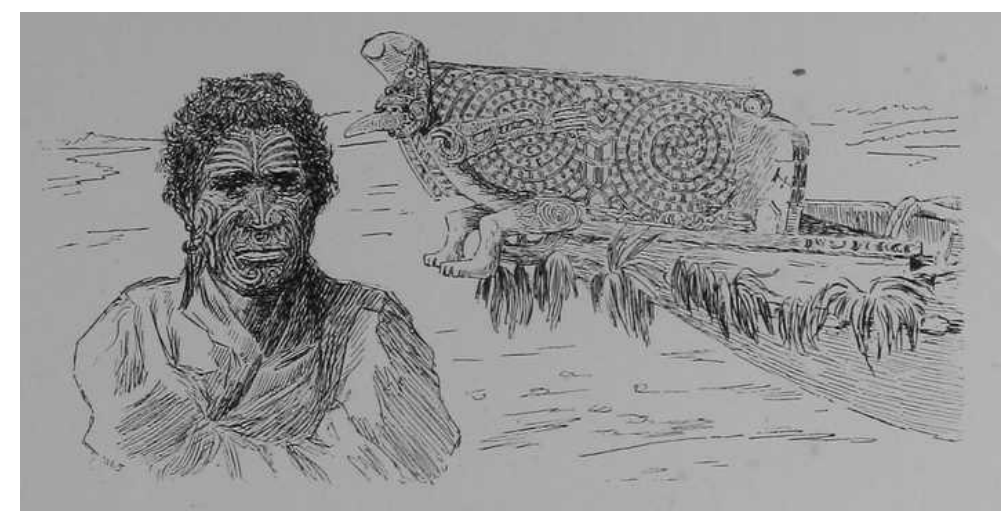

Fig. 5, Engraving of carved waka prow and face with moko in Horatio Robley's, Moko: or Maori Tattooing, 1896.

\footnotetext{
The Re-mystification of Taonga Whakairo - the Case of Te Mãori

After more than a century of traditional taonga whakairo being demystified, culturally neutralised, and converted into objects of indigenous New Zealand art, craft, or antiquity, redemption seemed at hand in the mid-1980s, with the commencement of the Te Maori exhibition. Although hundreds
} 
of thousands of people visited the exhibition in the United States and New Zealand, the lasting images of the exhibits were preserved in the form of photographs, particularly those reproduced in books which accompanied the exhibition.

It is at this juncture, though, that the traditional taonga whakairo became re-mystified. The language used encouraged viewers of the images to see them in a specific way. The texts described the exhibits in the photographs variously as 'haunting', 'extraordinary', 'mesmerizing', 'astonishing', and even 'modern' and 'highly abstract' (Turner, 2002, p. 83) traits that were accentuated by the use of visually dramatic photography (Moon, 2011). One of the exemplars of this was the image of Uenuku (fig. 6):

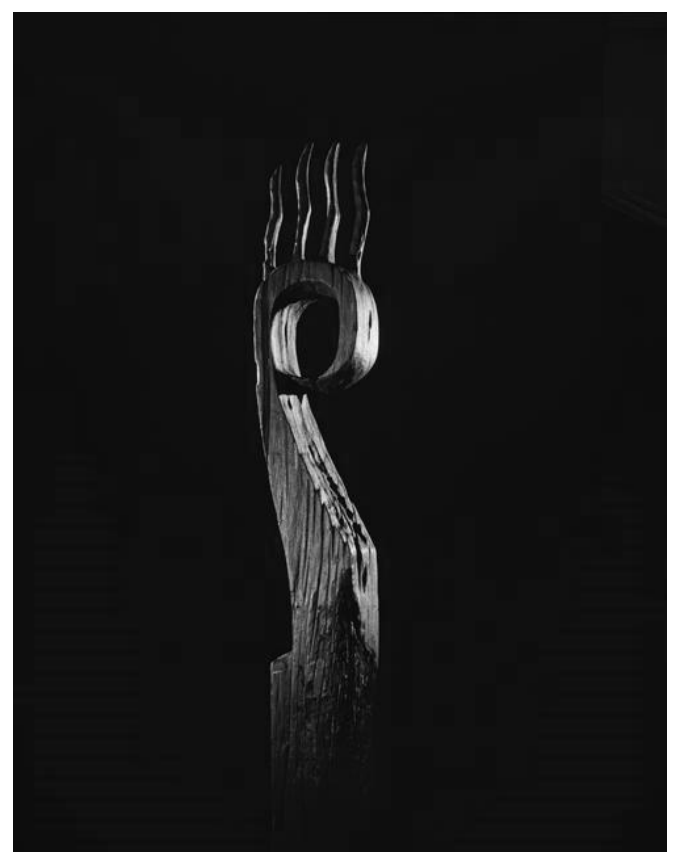

Fig. 6, Photograph of 'Uenuku', in Hirini Mead's, Te Maori, 1984. 
The technical manipulation of such images through the selection of lighting, backdrops, and composition, carefully conjured up the impression of ancient indigenous mysticism. Yet, the very act of putting these taonga whakairo on exhibition and producing thematically-loaded images of the exhibits was as much a continuation of the projection of these objects as art and antiquities as had been the case in previous generations of photographs of traditional Māori carvings. The difference, though, was with the re-mystification of the item which was not necessarily a reversion to traditional Maori notions of spirituality, but a new form of mystification (Hanson, 1989) based on the photographic imagery of the exhibits and the texts which encouraged particular ways of seeing them (Berger, 1972). 


\section{References}

Angas, G. F. (1866). Polynesia: a Popular Description of the Physical Features, Inhabitants, Natural History and Productions of the Islands of the Pacific. London: Society for Promoting Christian Knowledge.

Angas, G. F. (1847). Savage Life and Scenes in Australia and New Zealand. Vol. 1. London: Smith, Elder, and Co.

Berger, J. (1972). Ways of Seeing. London: Penguin Books.

Best, E. (1927). The Pa Maori, Wellington: Dominion Museum.

Best, E. (1934). The Maori As He Was: A Brief Account of Lie As It Was in Pre-European Days. Wellington: Dominion Museum.

Best, E. (1941). The Maori. Vol. 2. Wellington: Polynesian Society.

Brown, W. (1851). New Zealand and its Aborigines. London: J. \& D. A. Darling.

Hiroa, T. R. (1949). The Coming of the Maori. Wellington: Maori Purposes Fund Board.

Burton, W. (1885). Interior of house, Ohinemutu, albumen print. Auckland: Auckland Art Gallery Toi o Tāmaki.

Busby, J. (1866). Our Colonial Empire and the Case of New Zealand. Edinburgh: Williams and Norgate.

Carleton, H. (1874). The Life of Henry Williams, Archdeacon of Waimate. Auckland: Upland \& Co.

Centennial Branch, (1940). Official Guide to the Government Court N. Z. Centennial Exhibition 1939-1940. Wellington: Centennial Branch, Department of Internal Affairs.

Cowan, J. (1930). The Maori: Yesterday and To-Day. Christchurch: Whitcombe and Tombs.

Craik, G. L. (1830). The New Zealanders. London: Charles Knight.

Earle, A. (1832). A Narrative of Nine Months' Residence in New Zealand in 1827; Together with a Journal of a Residence in Tristan D'Acunha. An Island Situated Between South America and the Cape of Good Hope. London: Longman, Rees, Orme, Brown, Green \& Longman.

Gilpin, W. (1768). An Essay Upon Prints, Containing Remarks Upon the Principles of Picturesque Beauty. London: J. Robson.

Godber, A. P. (1934). Maori Carving: Revival of an Ancient Art. New Zealand Railways Magazine, 9(7), 39-41. 
Hanson, A, (1989). The Making of the Maori Culture: Culture Invention and its Logic. American Anthropologist, 91(4): 890-902.

Jackson, P. (1999). Commodity Cultures: The Traffic in Things. Transactions of the Institute of British Geographers, 24(1), 95-108.

Martin, S. M. (1845). New Zealand in a Series of Letters. London: Simmonds \& Ward.

Mead, H. M. ed. (1984). Te Maori : Maori Art from New Zealand Collections. Auckland: Heinemann.

Mead, H. M. (1986). Maori Wood-Carving. Auckland: Reed Publishing.

Mitira, T. H. (1944). Takitimu. Wellington: A. H. \& A. W. Reed.

Moon, P. (2011). New Zealand in the Twentieth Century: The Land, the People. Auckland: HarperCollins.

Polack, J. S. (1838). New Zealand, Being a Narrative of Travels and Adventures During a Residence in that Country Between the Years 1831 and 1837. Vol. 1. London: Richard Bentley.

Robley, H. G. (1896). Moko: or Maori Tattooing. London: Chapman and Hall.

Rusden, G. W. (1883). History of New Zealand. Vol. 1. Bungay: Clay and Taylor.

Ryan, C., \& Crotts, J. (1998). Carving and Tourism: A Maori Perspective. Annals of Tourism, 24(4), 898-918.

Skinner, D. (2008). The Carver and the Artist: Māori Art in the Twentieth Century. Auckland: Auckland University Press.

Swainson, W. (1859). New Zealand and its Colonization. London: Smith, Elder, and Co.

Taylor, R. (1855). Te Ika a Maui, or, New Zealand and its Inhabitants. London: Wertheim and McIntosh.

Taylor, A. L. (1977). Folk Traditions in Maori Art. Art New Zealand, 5, 18-22.

Turner, S. (2002). Sovereignty, or the Art of Being Native. Cultural Critique, 51, spring, 74-100.

Wade, W. (1842). A Journey in the Northern Island of New Zealand. Hobart: W. Pratt.

Wakefield, E. J. (1845). Adventure in New Zealand: from 1839 to 1844 With Some Account of the Beginning of the British Colonization of the Islands. Vol. 2. London: John Murray.

Williams, W. (1867). Christianity Among the New Zealanders. London: Seeley, Jackson, and Halliday. 
Willis, A. and Fry, T. (1988). Art as Ethnocide: The Case of Australia. Third Text. 2(5), 3-20. 